\title{
Taxing for Inequalities: Gender Budgeting in the Western Balkans
}

\section{Vesna Bojičić-Dželilović (a) \& Aida A. Hozić (b)}

a) London School of Economics, London, UK

b) Department of Political Science, University of Florida, Gainesville, FL, USA

Provide full correspondence details here including e-mail for the corresponding author

Department of International Development

London School of Economics and Political Science

Houghton St.; London WC2 2AE

v.bojicic-dzelilovic@1se.ac.uk 


\section{Taxing for Inequalities: Gender Budgeting in the Western Balkans}

This article seeks to illuminate structural limits of Gender Responsive Budgeting (GRB) by analysing the interplay between economic and fiscal reforms, promoted by International Financial Institutions (IFIs), and gender budgeting initiatives in the Western Balkans. GRB is the core concept bridging revenue mobilization and gender equality in the work of IFIs. However, as the Western Balkans experience demonstrates, GRB initiatives are best characterized as "empty gestures" towards gender equality as they cannot compensate for the continued adverse effects of IFIs overall policies.

Keywords: Gender Responsive Budgeting, VAT, Western Balkans, revenue mobilization, consumption-led growth, financialization, households

\section{Introduction}

Over the past decade, as the global economy sought recovery from the depths of the financial crisis, gender equality and women's empowerment have taken a much more prominent role in the work of the International Financial Institutions (IFIs), often serving as the focal point of connection between the IFIs traditional concerns such as economic growth and stabilization and the new objectives envisioned by the United Nations' (UN's) Millennium Goals and their successors Sustainable Development Goals (SDGs). While one of the SDGs - SDG5 - explicitly focuses on gender equality, most others can only be achieved with acknowledgment of women's role and participation in the economy, thus forcing the IFIs towards inclusion of gender in their analysis. In the International Monetary Fund (IMF), under the leadership of Christine Lagarde, gender equality has been recognized as a "macrocritical" issue, which means that it can now be subject to the IMF's formal policy interventions in and dialogue with member states (IMF 2018). At the World Bank, gender equality is seen as "central" to its "own goals of ending extreme poverty and boosting shared prosperity in a sustainable manner" and as "smart development policy" (World Bank Group 2015). In the IFIs research documents, the economic impact of the "gender gap" is usually described in terms of lost GDP while the benefits of bringing more women into the labor force find their expression in higher GDP growth as well as in increased productivity rates and changes in consumption patterns, home production, and leisure time (Dabla-Norris and Kochhar 2019; Lagarde and Ostry 2018). 
Simultaneously, taxation has emerged as a key development priority, also in relation to the SDGs and the Addis Ababa Action Agenda. Both the IMF and the World Bank emphasize domestic revenue mobilization as the solution to a range of issues that have long troubled the developing world, such as state- and capacity-building and dependence on foreign aid and debt accumulation, but also as the vehicle to attainment of the SDGs. According to Christine Lagarde (2016), revenue mobilization and international taxation are the main ingredients of the $21^{\text {st }}$ century economies: "robust government revenue," as she puts it, is the "lifeblood of modern states." And, at least in her view, there is an overlap between gender equality and revenue mobilization. Speaking at the Center for Strategic and International Studies in Washington D.C. on the International Women's Day in 2017, Lagarde emphasized that "the IMF wants to see countries implement gender budgeting, gender surveillance, and gender programming measures, and that the institution would be asking of any fiscal measures, structural reforms, or monetary policies adopted by countries, what is 'going to be supporting women's contribution to the economy?"' (Edwards 2017).

Gender Responsive Budgeting (GRB), highlighted by Lagarde in the above statement, is a concept - and a policy tool - increasingly viewed as a bridge between these two parallel agendas focused on gender and on domestic revenue mobilization. Initially introduced in Australia in 1984 (where the initiative would not last), GRB has since spread to more than 80 countries (Stotsky 2016). Across the world, adopted measures range from "modified fiscal policies and programs to ensure that the budget contributes to the closing of gender gaps and women's advancement" to collection and analysis of information "on the different needs of women and the differential effects of fiscal policies on women and men." The most elaborate GRB efforts (for instance in India, Mexico, Austria, Rwanda, and Ecuador) have led to changes in fiscal policies towards health and education or to greater gender-sensitive accountability in public spending. In the majority of countries, however, the most common practice is "setting up relevant administrative machineries or conducting training sessions for public officials" (Stotsky 2016). Thus, while aiming to make women's invisible labor and needs legitimate to the state fiscal and budgetary apparatus, most GRB efforts have not gone too far. Limited in their effect on the distribution of revenue, they have generally not even addressed the ways in which revenue is 
being mobilized - even though revenue mobilization has been, at times, an equally important consideration in GRB analysis by scholars and early advocates. This total disconnect between GRB as currently advanced and revenue mobilization will be a recurrent theme in this article.

This article seeks to illuminate the structural limits of GRB ambitions to advance gender equality outcomes by analyzing the interplay between IMF-promoted economic and fiscal reforms in the Western Balkans ${ }^{1}$, one of the key global post-conflict laboratories for international organizations, development agencies, and the IFIs. It was in Bosnia and Herzegovina, in the mid- 1990s, that the IMF made its foray into the post-war reconstruction and assumed a role of an 'external anchor' of economic transition in the Western Balkans (Bastian 2008), which has since become a widespread practice in conflict-affected and many developing countries worldwide. Our main argument in this analysis is quite straightforward - when examined in the context of the IFIs' reform packages, particularly in post-conflict spaces where the IFIs have even more leverage than in other developing countries (Boon 2007), even effective GRB initiatives encounter structural limitations arising from a combination of consumption taxation and government spending priorities against a backdrop of a reduced economy and the disproportionate influence of political divisions and incentives on spending. Externally funded consumption-led growth and financialization promoted by the IFIs, which both induce households into the global market economy with unsustainable levels of debt, when coupled with the introduction of VAT on household consumption and inadequate government spending, have generated vicious circles of gendered inequalities. Hence, in such contexts, GRB initiatives may be best characterized as empty gestures towards gender equality or as "pseudoactivities" (Spehar 2018) because - even if successful - they are unlikely to compensate for the overall impact of the IFIs policies, which continue to deepen gender gaps in the Western Balkans.

The structure of the article reflects feminist attentiveness to nested economic analysis linking macro-, meso-, and micro-economic levels, with their corresponding gendered biases: starting from aggregate savings and investment patterns and then moving to financial institutions and gendered divisions of labor and consumption patterns on household levels (Bakker 2001). After a brief overview of literature within which our article is situated and which explains the focus on differentiated gendered impact of economic reform policies in relation to the GRB initiatives, we 
shift our attention, in the first empirical section, to the trajectory of IMF's engagements in the Western Balkans with particular emphasis on consumption-led growth and financialization and their gendered effects on households. In the second section, we address the issue of revenue mobilization and its gendered implications by examining the adoption and diffusion of VAT throughout the region. In the third section, we discuss briefly the position of women in the Western Balkans and the introduction of GRB, whose ineffectiveness is usually blamed on poor implementation rather than structural impediments ascribed to broader fiscal policy decisions in a given economic context. In conclusion, we address the implications of our analysis for the GRB aspiration to improve gender equality outcomes in the context of IFIs activities, and we view attendant pairing of revenue mobilization with gender equalities as a way to mask on-going reproduction of inequalities in the global economy.

\section{Taxation and gender equality: a dialogue?}

Our article is situated at the nexus of two bodies of literature. On the one hand, our research is immersed within scholarship on international taxation and global tax reforms, in which the IFIs have played a critical role over the last few decades. On the other hand, we are inspired by feminist political economy, which has traditionally placed particular emphasis on reproductive (unpaid and/or informal) labor and on power/economic dynamics within households - both usually invisible from the perspective of mainstream economic theory and located beyond the reach of tax authorities. Despite impressive research in both areas and increased recognition in international economic policy circles that both gender equality and taxation matter, "they have rarely been discussed together and potential and existing links have largely been ignored in development cooperation" (OECD nd). Regrettably, as the introduction to this special issue underscores, feminist political economy is not yet fully integrated in mainstream economic policy and knowledge production. The way in which the IFIs address and/or include in their

work in the Western Balkans - despite decades of scholarship, activism, and expert advice on GRB benefits, including inside the IFIs - is an excellent example of this persistent marginalization of feminist approaches to political economy. 
There is a general consensus in the literature on global tax reforms that IFIs - and the IMF in particular - have been the key promoters of neoliberal tax policies, especially in the developing world (Seelkopf, Lierse and Schmitt 2016; Genschel and Seelkopf 2016; James 2015). Duane Swank (2016), for instance, has persuasively argued that participation in the IMF programs makes adoption of VAT more likely. There is also considerable agreement among researchers on the substance of tax reforms, whose essence is best captured by Aizenman and Jinjarak (2007) notion of the shift "from 'easy to collect' taxes (tariffs and seigniorage) towards 'hard to collect' taxes (value added and income taxes)." More specifically, Reinsberg, Stubbs and Kentikelenis (2017) argue that " while there is no effect of IMF programs on total tax revenue, IMF programs promote goods and services taxes" and "decrease the revenue collected from personal income tax and corporate income tax in the long run", which is a view contradicted by the IMF's own research. Recent scholarship on international taxation focuses on the aspects where there is still some divergence among tax reform adopters, examining the interplay between powerful international forces such as globalization and the influence of IFI's and domestic politics that include institutions, coalitions, and political regimes (Bastiens and Rudra 2018; Swank 2016a). In addition, scholars have explored dynamics and patterns of diffusion of specific tax policies among certain groups of states (Swank and Steinmo 2002; Keen and Lockwood 2010; Appel 2011; Appel and Orenstein 2013; Swank 2016). Finally, research has centered on the effectiveness and the impact of new tax regimes, primarily in relation to state capacity, state building, and democratic politics or on economic growth and inequality (Braütigam, Fjeldstad and Moore 2008; Di John 2016). However, it is important to note, most of this research remains wedded to traditional actors in international politics (states and international organizations, occasionally NGOs) and their standard categorizations and measurements (rich countries versus developed world, aggregate accounts such as tax revenue vs GDP, etc).

Feminist political economists have long sought to insert their perspectives into these debates by warning that tax policies - not just government expenditures - have differential effects on men and women (Stotsky 1996; Stotsky 1997; Elson 1999; Elson and Cagatay 1999; Bakker 2001; Budlender et al. 2002; Budlender and Hewitt 2002; Grown and Valodia 2010; Casale 2012) and can be further compounded by other factors such as race, ethnicity, age, etc (Women's Budget Group 2017). The groundbreaking publication by The Commonwealth Secretariat Gender 
Budgets Make Cents (Budlender et al. 2002), emphasized that the precondition of any potential conversation about these differentiated effects and implications of taxation is to disaggregate the data according to the differential impacts on men and women. Obviously, any dialogue between scholars and policy makers and feminist political economists would be predicated on acknowledgment of reproductive labor and gender-disaggregated households as units of analysis. And that, as Elson (2002) explained, requires a new set of analytical tools in budget assessments: whereas most budget analyses focus on effectiveness "in terms of achieving the intended results at the lowest possible cost," gender analysis asks very different questions: "Result for whom?" and "Costs for Whom?"

GRB has become a programmatic policy response aiming to link these seemingly incommensurable research agendas because it provides "a practical way to take the gender mainstreaming agenda into the most powerful departments of government." (Elson 2001). The diffusion of GRB and its adoption by the IFIs owes much to the pioneering scholarship of such feminist economists as Rhonda Sharp, Diane Elson and Debbie Budlender, to the civil society organizations such as the Women's Budget Initiative in South Africa and the Women's Budget Group in the United Kingdom, and to the Gender Affairs Department of the Commonwealth Secretariat, which spearheaded the implementation of GRBs in several pilot countries in the mid1990s (Sawer 2012). Subsequently, gender budgeting would be incorporated in the work of other international organizations to eventually reach the IMF and the World Bank. Even within the IFIs, the consideration given to GRB has been the result of volunteer research by dedicated women economists, who have worked on gender issues "in addition to their core work" (True and Svedberg 2019).

Against this background, there are three themes in the academic and policy conversations about GRBs that we wish to highlight and that provide a motivation for the analysis of the gendered impact of conventional IMF's policies in the post-conflict Western Balkans presented in this article. The first theme stressed by GRB scholarship is the relationship between gender equality and tax effectiveness. The premise of most work on gender, budgets and taxation is the idea that gender inequalities generate economic inefficiencies. Exclusion of women, neglect of differential and gendered effects of taxation, discounting of unpaid work, lack of investment in sectors such 
as healthcare and education take their toll on economies, inevitably shrinking the tax revenue base. Therefore, scholars and advocates insist, gender budgets "are not separate budgets for women, or budgets which spend the same amount on women and men, but budgets which recognise the different situation and needs of women and men and aim to promote gender equality" (Women's Budget Group 2017).

Second, despite (or because of) this careful balancing of equality and efficacy in advocacy for GRB, feminist scholars have always been very careful to warn against instrumentalization of women and gender in policy making, particularly in economically, institutionally and politically fragile settings. Diane Elson (2002) was very explicit that "recognizing gender inequality as an efficiency issue does not mean seeing women instrumentally as a resource to be used by others for increasing productivity and growth." These concerns have only been heightened in this era of "neoliberalization of feminism," in which "neoliberal economics and liberal feminist values of equality co-constitute each other" (Prügl 2017). Thus, although gender budgeting can "make cents" (Budlender and Hewitt 2002), the pursuit of gender equality should not be made subservient to market rationality or to notions of development exclusively defined in terms of economic growth and increased productivity.

Finally, the third theme, which is particularly important for our analysis of GRB initiatives in the Western Balkans, is the importance of both revenue and expenditure for gender equality outcomes. Early advocates of GRB (Budlender et al. 2002) already noted that revenue tended to be neglected in gender-sensitive analyses and insisted that "tools for revenue analysis also need to be developed that look at direct and indirect taxation and at user financing of basic social services." Sharp and Elson (2008) also highlighted that "taxation (and other revenue raising) and expenditure should be considered together for a full understanding of the effects of budgets." And yet, two decades into GRB diffusion, the revenue side of the budget equation - as the case of Western Balkan will also confirm - continues to be ignored. In her survey of gender budgeting efforts in Europe, Quinn (2016) found that "the practice of gender budgeting across Europe is almost exclusively associated with the expenditure side of the budget, and in particular with expenditure related to the delivery of public services", notwithstanding initiatives in some, mostly West European countries to eliminate explicit gender bias in their tax systems (Stotsky 
1996:3) This one-dimensional focus of GRB, as we demonstrate in the rest of this article, may be the main hurdle to its effectiveness in addressing gender inequalities.

\section{IMF in the Western Balkans: the big picture}

In the last decade of the Twentieth Century, the IMF's most significant engagements were in the economic transitions of the former socialist countries and in fragile and conflict-affected countries. The Western Balkans, where these two projects overlapped to a great extent, became the prime site of experimentation for the IMF's extended role in economic restructuring and transformation. The 'mission creep' to post-conflict reconstruction, which expanded the IMF's scope of action, also increased its leverage over the domestic reform processes to steer economic policies and structural reforms toward financialization and consumption-led growth with distinctive impacts on gender equality outcomes.

Between 1992 and 2015, a total of 29 financial arrangements worth SDR8.2bn were agreed to with the governments of the Western Balkan countries to provide emergency post-conflict assistance, and to back financially and by means of technical support the region's economic transition to open market-based economies (Table 1). The IMF's involvement in the Western Balkans demonstrates that the Fund did not stray away from its standard neoliberal policy recommendations and conditionalities regardless of the very different context for its operations. Under the IMF auspices, the Western Balkan countries went through the full gamut of the standard fiscal and financial stabilization policy reforms explicitly focused on macroeconomic stability objectives (Murgasova 2015:61; Momani and Hibben 2018), to which poverty reduction and structural reform were added in 2000-2008. In the aftermath of the global financial crisis the IMF took a more varied policy approach - mainly in terms of how conditionality was implemented - while keeping within the austerity policy framework, which did little to reverse a cumulative impact of economic reforms on deepening gender inequality.

Table 1 shows that in 1992-2015, IMF lending was dominated by stand- by arrangements intended to correct for short-term balance of payment distortions. Such a lending portfolio profile indicates that in practice no allowance was made for distinctive conditions in the Western 
Balkans arising from a combination of war-related destruction and disruption of the former Yugoslavia's single economic and political space, and Albania's uniquely autarchic economy, which required extensive structural transformation over an extended period of time. Or for the fact, only recognized many years later by the IMF itself, that in the Western Balkans, particularly in countries with a direct experience of conflict, including Bosnia and Herzegovina, Kosovo, Croatia and FYR Macedonia, the political cycle had a disproportionate effect on economic policy making, especially on fiscal spending policies with explicit negative consequences on gender equality outcomes (Murgasova et al. 2015: 51).

According to the IMF's economic growth model, resumption in economic growth as the economy stabilizes, generates new employment and boosts public revenue with a positive and mutually reinforcing impact on gender relations (Perrons 2017). Accordingly, to re-start economic growth in the Western Balkans, the IMF pushed for trade and financial liberalization alongside privatization and banking sector reform (Bastian 2010). Simultaneously, the IMF required that Western Balkan governments implement the conventional fiscal consolidation package consisting of a mix of public expenditure cuts, the implementation and increase in consumption taxation, welfare and labor market reforms aimed at public deficit reduction, and public debt control. Contrary to the IMF's claims to have adapted its operational practices to better suit local country contexts thus reducing need for conditionality (Momani and Hibben 2018: 84), conditionality was a strong feature in the Western Balkans. Serbia, FYR Macedonia, and Bosnia and Herzegovina were among the countries with the highest number of conditions attached to IMF lending in 2004-2014 (Kentikelenis et al. 2016:553-4), with a significant increase in structural conditionalities in the financial sector after the global financial crisis.

Opening of the Western Balkans' economies to global processes of financialization through swift and abrupt liberalization and privatization, coupled with high dependence on remittances and international aid, contributed to structural transformation processes which fostered externally funded consumption over production in the real economy, the cumulative effect of which was particularly harmful to women (World Bank 2017a). A distinct feature of such transformation was an excessive and 'premature' decline in industry, notably in manufacturing, given the levels of development in the Western Balkans with a chain effect on macroeconomic and employment 
outcomes (Damiani and Uvalić 2018; Sanfey et al. 2016: 14-15). A reduction in the domestic productive base dominated by a particular mix of services, locked the Western Balkan countries into a cycle of low competitiveness and persistent foreign trade and balance of payments deficits and high unemployment, particularly among women and youth (Bartlett 2009:26; Murgasova et al. 2015:13; Sanfey et al. 2016:4 World Bank 2008:1). For example, the textile industry in which the female workforce had been prevalent, was almost decimated as a result of neoliberal restructuring; in Serbia the number of textile workers contracted from 160,000 in 1990 to 40,000 in 2010 (Udovički and Knaus 2012). Udovički and Knaus argue that blind acceptance of IFIspromoted growth model underlying such structural shifts, has even discouraged the governments from asking why recovery in the textile industry was not possible.

The emergence of a particular variety of the Western Balkans' consumption-led economic growth model that disproportionately harmed women as economic agents and in their role in the reproductive economy, can be linked to the policies of privatization and financial sector liberalization, the two fundamental structural reforms to catalyze private sector development according to the neoliberal economic doctrine that informs the IMF approach. The results of privatization, notably in the industrial sector which under a socialist economy provided secure and well-remunerated jobs alongside various benefits targeted at women (such as subsidized childcare, reproductive health provisions, and subsidized family holidays) were far more modest than the IMF and its local counterparts had anticipated (Estrin and Uvalić 2016). As the IMF has come to recognize more recently, the adverse gender effects of privatization in the Western Balkans were manifested through loss of employment, proliferation of precarious work, and unresolved social welfare for the workforce in companies designated for sale. Foreign direct investment (FDI) concentrated in the sectors intended for domestic consumption, including financial services, real estate, retail trade, and telecommunications at the expense of industry and construction. By 2008, through financial liberalization, between 70 and $95 \%$ of domestic banking assets were transferred to foreign-owned banks, which flooded the region with commercial loans fueling consumption in the period before the global financial crisis (Sanfey et al. 2016; IMF 2017: 99; IMF 2017; Bastian 2010). 
Exceptionally strong capital inflows were unwarranted by the Western Balkan countries fundamentals $^{2}$ (IMF 2017: 99-100; Murgasova et al. 2015: 13; Sanfey et al. 2016: 2; Bakker and Rahman 2013), and instead were spurred by the ample liquidity in the global financial markets and low interest rates. The credit-to-GDP ratio increased by an average of 30\% of GDP in 20002008 and ranged from $20 \%$ in Serbia to 70\% in Montenegro (IMF 2017:100). Significantly, between 2004-2008 in each country, household credit growth outpaced lending to corporations as the profit earning potential in the household sector proved far more attractive than investment opportunities in the underdeveloped business sector that had been distorted under the impact of successive regional wars and prolonged transitional recession (Becker et al. 2010:12; Damiani and Uvalic 2018; Bastian 2010). Throughout the 2000s, household credit expansion provided a major impetus to consumption driven growth in the Western Balkans. Household consumption also benefited from rising wages, particularly in financial services and public administration, whose share in the economy expanded as industry contracted, even though employment levels overall remained subdued as testified by unemployment rates averaging $25 \%$ in 2015 (Murgasova et al. 2015:20; World Bank 2008; WIIW 2017). Another source fueling household consumption were remittances spurred by large war- and transition-induced outward migration. They provided financial lifelines for cash stripped-families as well as a source of capital to run small businesses and create employment in the face of particularly limited job opportunities available to the female labor force as a result of structural transformations in the economy. Prior to the global financial crisis, remittances were a critical source to plug the balance of payments gap arising from weak export performance (Bastian 2010). In the aftermath of the global financial crisis, although remittances inflow weakened, they exceeded FDI volume throughout the region, with the exception of Montenegro (World Bank 2017b; IMF 2014).

While commercial credit and strong remittances inflows increased household purchasing power and propped up living standards eroded by the loss in employment by men and women alike through rapid deindustrialization, and by welfare cuts through fiscal consolidation (IMF 2017:101), there was also a more sinister side to the buoyancy of externally-funded consumption growth. Especially in Croatia and Montenegro, where the tourist industry spurred a real estate boom, affiliates of the West European banks pursued mortgage lending by aggressively taking advantage of a demand created by an ideological shift towards the primacy of private ownership under the neoliberal model championed by the IMF, and the rising value of credit collateral. In 
all Western Balkans countries, fast lending growth overwhelmed banks' risk management capacity. Also, especially in the case of mortgage lending, it was a development of lucrative markets which contributed to the banks' lax risk assessment procedures. Often, the outcome was a striking growth in the levels of household debt (except in Albania and Serbia) that were recorded in the build-up to the global economic crisis (Makrevska-Disoska 2017). Loans linked to foreign currency or denominated in foreign currency turned out to be particularly risky to households lacking stable access to foreign currency and more generally stable sources of income. The share of consumer credit denominated in (or indexed) to foreign currency such as the Euro, US dollar and Swiss franc ranged between 70\% and 80\% in Croatia, Bosnia and Herzegovina, and Serbia as borrowers sought to take advantage of lower interest rates on those loans and the local currency appreciation (EBRD 2009: 44). To the banks, such loans provided protection against local currency depreciations, but increased the risks of exchange rate fluctuations to the borrowers in the household sector with no access to foreign currency.

The financial turmoil triggered by the global crisis which caused sharp fluctuations in foreign currency exchange rates, was particularly devastating for the holders of loans denominated in Swiss francs which rose sharply in 2008. According to Rodik (2012), the banks' imprudent business practices were partly responsible for their surge. She explains how the banks failed to clarify the terms of variable interest rate clauses applied to the Swiss franc denominated loans (or indexed to the Swiss franc) and how they aggressively advertised cheap mortgage loans in full knowledge that interest rates could be altered at any point after the loan was approved. When the exchange rate changed, particularly in Croatia where mortgage borrowing represented a larger share of those loans, debt repayment burden for households with no access to foreign currency caused significant distress.

Similarly, access to and dependence on remittances proved a double-edged sword in terms of household well-being and gender relations in the Western Balkans. Remittances tend to flow to men in the Western Balkans; in Kosovo, where over 20 per cent of households receive remittances, in two out of three cases remittances flow from men to men (Farnsweden et al. 2014:18). Being an unstable source of income, which was slashed under the impact of the global financial crisis, in the long run remittances contributed to the economic insecurity of women 
depending on this source to sustain household budgets. Furthermore, remittances reinforce disincentives to the female participation in the Westerns Balkans labor markets which provide limited opportunities for gainful employment.

The macroeconomic effects of IMF-supported reform processes have been equally ambivalent from the standpoint of advancing gender equality. Revival in economic growth and improved fiscal performance rest on fragile foundations due to local economies' 'structural deformations' (Damiani and Uvalić 2018). These are manifested in the persistent weakness in the tradable sector and low competitiveness that all Western Balkans countries suffer from after nearly three decades of open market reforms experience (hence persistence of balance of payments gaps). As a consequence of the reduced productive base, the domestic fiscal base is narrow and revenue generation disproportionately reliant on externally funded consumption. A reduced and unstable domestic fiscal base as an unintended consequence of following IMF policy prescription sis at odds with the purported ambition to reorient fiscal policy towards gender equality objectives promoted by the IMF and (declaratively) embraced by the Western Balkan governments, which require more and better targeted resources. The task of reorienting fiscal policy with its inherent gender biases to advance substantive gender equality is further complicated by a combination of the manifold challenges of implementing efficient taxation and public spending policies in the Western Balkans posed by the region's legacy of conflict. We discuss these challenges in the context of VAT implementation and its gendered effects in the next section.

\section{VAT and gendered effects of fiscal policy in the Western Balkans}

During the early years of supporting transition in the Western Balkans, the IMF initially focused on fiscal consolidation only to shift later to revenue mobilization in response to the local governments' failure to correct fiscal imbalances and improve government finance in a sustainable way. Taxation reform became the order of the day, strengthened further through the European Union accession process which requires the Western Balkans governments to harmonize country taxation systems with that of the EU (Perrons 2015; Sanfey et al. 2016). Increasing tax rates and introducing the value added tax (VAT) swiftly became the key reforms reflecting the IMF's preoccupation with the aggregate targets in terms of revenues. The proposed reforms mirrored the IMF's approach to fiscal consolidation targeting the size of fiscal deficit 
while paying less attention to the composition of fiscal adjustment. Much less consideration was afforded to the way and the speed with which public revenue was mobilised. In so doing, the IMF ignored the pernicious effects that indirect taxation reforms would have on households, and particularly on women, against the backdrop of cumulative negative impacts suffered under the externally funded consumption growth model which we discussed in the previous section.

VAT is a preferred taxation instrument worldwide. Its diffusion, especially in the developing world, can be attributed to two factors - the need for newly liberalized economies to find alternative sources of revenue, which would compensate for the loss of custom duties and tariffs, and the active promotion of VAT by IFIs and the European Union (Seelkopf, Lierse and Schmitt 2016; James 2016). VAT is considered neutral in respect to several divisions in the economic world - between production and distribution, manufacturers and merchants, between capital and labor intensive products, between corporate and non-corporate entities, and between integrated and specialized firms. Proponents of VAT argue it is a simple, predictable, stable and flexible source of revenue since consumption is fairly constant; therefore, even the slightest variation in the rate is likely to produce a change in the revenue (OECD 1998:10). Because of the VAT's ability to tie producers, wholesalers and retailers into a single taxation chain, it minimizes incentives for fraud and tax evasion. It is also regarded as a self-policing and self-enforcing tax. Finally, VAT is also particularly well suited for the monitoring and enhancement of international trade; it has allowed for a simultaneous push in consumption taxes and seamless cross-border transactions. It is then relatively clear why VAT has become the preferred method of taxation in the age of economic liberalization and a standard instrument in the IMF policy toolkit. VAT, and especially a uniform VAT rate, have become something of a gold standard in the IMF practice (Bretton Woods Project 2019).

At the same time, as feminist political economists have been warning for decades, VAT is hardly neutral in its effects on social and economic equality, including gender equality. While VAT's neutrality in terms of facilitating unencumbered business is central to the IMF's growth-oriented taxation approach, the consideration of its redistributive effects both regarding different types of households as well as gender household relations is a blind spot in IMF practice (Grown and Valodia 2010; Elson 2010:205). ${ }^{3}$ As a consumption tax, whose burden always ultimately falls on 
the final user, VAT quite obviously disproportionately affects the poor and has, at the very least, an implicit gendered bias. Janet Stotsky's $(1996,1997)$ pioneering work on indirect taxation argues that implicit - if not explicit - biases stem from different household consumption practices based on their (gender) composition. Excise taxes on goods such as tobacco and alcohol may, for instance, be implicitly biased against men while flat-rated VAT on food, medical goods, and educational supplies may adversely affect women, who tend to be their primary consumers on behalf of families, but especially in single female-headed households. Other feminist economists, like Elson, contest the use of the term "bias" because it means "unjustly different" not simply "different." According to Elson, there is nothing unjust about imposing high tax rates on socially detrimental goods like alcohol and tobacco, or about exempting socially desirable goods like medical supplies. Rather, Elson argues, the term "bias" is "misleading in the context in which women's incomes are typically lower than men's." In her view, any “conclusions about 'bias' in a tax system have to be related to women's and men's ability to pay" (Enriquez and Elson 2012: 301).

Besides its implicit gender bias due to different consumption patterns and pay ability between women and men, VAT can also adversely affect women through other channels. High VAT rates can dampen the supply of female labour by eroding wages. VAT can also affect women's decisions to buy goods in the market and/or produce them themselves, and thus increase the burden of unpaid work (Quinn ibid: 40) and/or participation of women in informal markets, as consumers and laborers. Buenaventura and Miranda (2017: 9) argue that VAT can be not only regressive but also gender discriminatory in its effect on lower earnings groups where women are disproportionately represented. VAT evasion and avoidance (for example through nonregistration, undervaluation, underreporting, misclassification) as an aspect of tax evasion may have additional gendered effects. VAT evasion undercuts aggregate tax revenue which can reduce economic and social investment in a country that women typically rely on more than men. Women entrepreneurs, typically owners of small and medium enterprises, may bear disproportionally the costs of VAT evasion by large companies in terms of reduced competitiveness. SMEs owned by women are often in the informal sector and cannot always easily claim or process VAT refunds. When registered, their business may fall below the VAT threshold - but even if they do not have to pay VAT on the final goods, they cannot claim VAT 
refunds for the inputs which are usually sourced at higher costs due to the lack of access to formal sources of finance. Women owning SME often lack time and expertise to claim VAT refunds or to look for cheaper inputs, all of which ultimately make their business less competitive. There are other types of gendered impacts of VAT evasion depending on the VAT regime, such as the impact of inheritance taxation.

In some developing countries the VAT systems build in pro-poor and pro-gender instruments by the implementation of differential VAT rates and broad exemptions (Grown and Valodia 2010: 14). Applying reduced VAT rates either through lower standard rates, zero rates or exemptions on goods and services used in the care economy may benefit women, particularly in femaleheaded households (Quinn 2016). For instance, the Trinidad and Tobago VAT regime before 2016 applied numerous zero and reduced rates and exemptions which included zero rates for basic goods and exemptions for health services, most of education, rental of residential property, and bus and postal services (Buenaventura and Miranda 2017: 10). Similarly, the Vietnamese VAT, at the time of the study, contained 27 categories of exemptions (Barnett and Grown 2004:39; 41), which reduced the tax burden on the poor while being effective in revenue generation. In Uganda, the high VAT is coupled with one of the world's longest lists of zero rated exemptions that include goods and services such as food, medicine, education, health, and livestock that account for a disproportionate share of spending by poor households and women. In Indonesia, where the malnutrition rate is high, basic food is exempted from the tax as are most agricultural inputs and food sold in restaurants, hotels and other catering outlets (Grown and Valodia 2010). And in South Africa, VAT is designed with particular attention to distributional effects, and applies zero rates to certain foodstuffs, paraffin, bread, maize, beans, milk, rice, cooking oil, etc. that women mostly purchase for their families (in the case of paraffin, these are mostly poor women) (Birchall and Fontana 2015).

The evolution of the VAT implementation in the Western Balkans 
The introduction of VAT in the Western Balkans proceeded at a different pace in different countries. In some states, the adoption of VAT was surrounded by political controversy. Croatia was a frontrunner, driven by its ambition to start the European Union accession process. Due to its obligation to harmonize the taxation system with other EU countries, it passed the necessary legislation as early as 1995. However, the government delayed the introduction of VAT by three years fearing the electoral backlash because of its adverse economic and social impacts. Montenegro adopted the law in 2001, which came into force in 2003. In Bosnia and Herzegovina, VAT was introduced within the framework of IMF-mandated reforms in 2006 and faced significant political opposition and public protests. The design of VAT policy itself, including the tax rates and structure, was influenced by the relative bargaining power that local governments had in negotiating fiscal targets with the IMF. Another consideration was weak institutional capacity given that under command economy no taxation system akin to market economy existed (Ganev 2011). Although the IMF has a clear preference for a single VAT tax rate on the grounds of tax efficiency and the ease of implementation - concerns that are of particular merit given the weak tax infrastructure in the Western Balkans, in all countries except for Bosnia and Herzegovina, differentiated VAT rates have been implemented over time. Most countries increased VAT rates in response to the recession triggered by the global economic crisis (Table 2).

\section{Table 2 HERE}

In Albania, Bosnia and Herzegovina, and Montenegro VAT exemptions or lower tax rates are limited on basic commodities with disproportionate weight in the female consumption basket, such as food, education, health, water and transport, while Kosovo law provides for the broadest scope of basic commodities carrying the reduced VAT rate (ALTAX 2016). ${ }^{4}$ The structure of VAT rates on essential commodities contrasts with widespread VAT exemptions of financial services, notably in Croatia, Albania, Bosnia and Herzegovina, and Kosovo (ALTAX 2016). Specific sectors such as tourism in Croatia and Montenegro, as well as gambling and betting are excluded from VAT. The practice of zero or limited exemptions stems from the preoccupation with technical expediency in operating VAT system. But in the context of high unemployment, widespread illicit and informal activities and post-war recovery, including re-integration of veterans (and war criminals) in the economy, it is difficult to overstate the gendered effects of 
these exemptions. They resonate with the financial capital interests which in post-conflict context are often congruent with the interests of the politico-economic elites. For the local authorities, poverty reduction and inclusivity are second order priority which in practice generally escapes the stick of IMF conditionality (IMF 2017).

\section{VAT performance}

Up until the global economic crisis of 2007-8, strong household consumption and strong imports associated with the economic growth model under the aegis of the IMF and other international institutions were key to strong VAT performance. Post-crisis, despite prolonged recession and slow recovery, VAT, except in Serbia, accounted for the highest share of GDP of all taxes in 2016, ranging from 10.6 per cent in Kosovo to 19 per cent in Bosnia and Herzegovina, significantly above the EU28 average of 7.9 per cent (IMF 2016:27; World Bank 2017b:108; IMF 2015). VAT constituted the most important source of indirect taxation which contributed between 40.4 per cent of government revenue in Bosnia and Herzegovina and 71.6 per cent in Kosovo in 2012, surpassing by wide margin the EU28 average of 30 per cent, and resembling more closely the patterns typical of low income countries (IMF 2015: 13; Koczan 2015: 4). Household consumption contributes the overwhelming portion of VAT revenue. A heavy emphasis on mobilising government revenue through taxing consumption, including of households exposed to the extremes of economic hardship of wars and protracted economic transition, conflicts with a relentless drive to cut corporate taxes which are among the lowest in Europe (World Bank 2017b).

Arguably, the introduction of VAT was instrumental in improving government revenue. But its performance has been volatile due to two structural features, namely the reliance on external financing to maintain consumption and the Western Balkans economies' dependence on EU markets. Vulnerability to external conditions as a consequence of distorted structural changes through prolonged implementation of IMF- style policies, was fully exposed in the aftermath of the global financial crisis. That in 2010-15, except in Montenegro, remittances outpaced FDI, is striking as well as revealing of an incongruous reinsertion of the Western Balkans in the global capitalist mainstream which reinforced the consumption-production imbalance in the economic 
growth model with all its unintended, negative consequences on these economies in terms of high unemployment, weak private sector growth, and macroeconomic imbalances (MakrevskaDisoska 2017:31; Damiani and Uvalić 2018). As the World Bank report (2017b) belatedly admits, changing the growth model is critical for the region's economic prospects as well as for the widening of the fiscal base to increase the space for productive spending that can target gender inequality more effectively as purported by GRB initiatives.

Tax evasion, with its accompanying gendered effects - both through fiscal channels as well as in its direct impact on some categories of women - is a serious problem in the Western Balkans. VAT and corporate income taxes are the most common forms of tax evasion. Between 2008 and 2015 tax evasion as a percentage of GDP averaged in Bosnia and Herzegovina (8.25\%), Croatia (5.72\%), Macedonia (5.93\%), Montenegro (6.88\%), Serbia (7.2\%) (Crnogorac and Lago Peñas 2018). A distinctive feature is VAT evasion related to the large shadow economy. VAT loss due to the shadow economy amounted to $28 \%$ of collected VAT in Croatia compared to $23 \%$ in Greece in 2015, one of the EU frontrunners in VAT evasion. The lowest VAT loss due to the shadow economy in the EU was recorded in Austria (8\%) (Frunza 2017: 10). Since the shadow economy in Croatia (the only EU member state in the region) is smaller than in other Western Balkans countries, VAT loss due to the shadow economy is likely to be larger in the rest of the region.

However, while tax compliance continues to occupy IFI officials and representatives of the international community in the region focused on improving tax enforcement, the structural limits on revenue mobilization caused by overall macro-economic policy, which are far more important in the context of the Western Balkans' economic and political setting, continue to be unaddressed. The economic crisis revealed that the efforts to improve tax enforcement as part of the IMF-supported taxation reforms could not fully compensate for the limitations imposed on the fiscal capacity in the Western Balkans by the weak productive base and uncompetitive economy- and by the high unemployment as their consequence. Stability of VAT revenue thus proved difficult to ensure in the Western Balkans and if anything, VAT revenue fluctuations contributed to procyclical public spending dominated by social benefits and public sector wages. While social spending ranges from $1.2 \%$ of GDP in FYR Macedonia to $2.8 \%$ in Kosovo (World 
Bank 2017a:111), it is not designed to support the poor or to promote gender equality policies and programs, all of which remain a second order social priority in government spending.

Social benefits are an important source of income particularly for poor households, and in Bosnia and Herzegovina, Croatia, and Kosovo also for certain categories of women, including war widows and civilian victims of war. But except in Albania, FRY Macedonia, and Montenegro, welfare spending has often privileged certain interest groups (World Bank 2017a; Stubbs and Zrinščak 2009). Those groups include demobilised soldiers who in Bosnia and Herzegovina, Croatia, and Kosovo are important electoral body for the ethno- national political parties, and whose entitlements successive governments were reluctant to cut. Welfare reforms only moved to the centre of austerity-driven government policies in the aftermath of the global financial crisis under the international fiat to effect sharp reduction in welfare benefits. Cutting social security and pension entitlements increases a squeeze on household budgets and a burden in sustaining a household which is firmly lodged with women under the prevailing social norms in the Western Balkans. The overall effect of policies that neglect women's priorities is to reinforce the adverse effects of high VAT on household gender relations.

\section{Gender equality in the Western Balkans: GRB Initiatives, detractions and failures}

At the end of the Yugoslav wars of the 1990s, women in the Western Balkans were often the focus of international attention. They were victims of war-time violence, sexual exploits of human trafficking, and treasured witnesses of war-crimes prosecutions at the International Criminal Tribunal for the former Yugoslavia in The Hague. They were also employees (interpreters, secretaries, local administrators) in numerous international and non-governmental organizations and, thus, invaluable contributors of "local knowledge" to the machinery of humanitarian intervention and peacebuilding, which settled in the Western Balkans as it became the exemplary "post-conflict" zone. With most men out of work in the war-ravaged economies, women were supposed to be the agents of recovery. Two decades later, however, "nearly twothirds of women in the Western Balkans are either outside the labor force or are unemployed" (Atoyan and Rahman 2017). Despite numerous initiatives, including legislative changes intent on promoting gender equality and participation such as gender-based quotas, most women in the 
Western Balkans are now on the margins of political life and, at least officially, economically inactive. Women labor participation in the Western Balkans ranges between $18 \%$ in Kosovo and 45\% in Serbia and Albania (European Fund for the Balkans 2018) while gender-based violence, gender stereotyping, low rates of political participation and slow progress on gender mainstreaming paint a bleak picture of gender equality in the region where women once occupied prominent positions in all aspects of social, political, and economic life.

It is, therefore, in this context of contradictory gendered signals and incentives - and against the backdrop of the IFI's macro-economic policies and tax reforms described in the previous two sections - that we must analyze the introduction of GRB in the Western Balkans economies, occasionally highlighted as "the only area [of gender-mainstreaming] where some progress is noted" (European Fund for the Balkans 2018). GRB initiatives arrived into the Western Balkans in mid-2000s as a "rich tool," which could "provide information that allows for better decisionmaking on how policies and priorities should be implemented and financed in order to achieve the goal of gender equality in different areas of life" (UNIFEM 2010). The introduction of GRB coincided with or came at the tail end of other IFI-induced reforms of public financing, including tax reforms, which were discussed in the previous section. Interestingly, the public financing reforms created expectations that GRB would be more easily accepted because they allowed "for a policy making and budgeting process that is more needs-based, transparent, accountable and participatory" (UNIFEM 2010). However, since the concept of gender budgeting was "new," and the region assumed to be burdened with "traditional values," the process of its implementation was slow and uneven. Indeed, the same UNIFEM (2010) report on GRB found that "a fullyfledged foundation for GRB work did not exist" in any of the countries they surveyed (Albania, Bosnia and Herzegovina, Serbia, and Former Yugoslav Republic of Macedonia).

The first GRB project, under the auspices of UNIFEM was implemented between 2006 and 2010 in four countries - Albania, Bosnia and Herzegovina, FYR Macedonia, and Serbia. The program focused on capacity building among stakeholders (government officials, civil society associations, and external researchers) and identified thematic areas in each country (education, agriculture, local economic development, etc.) that could be targeted by GRB (UNIFEM 2010). The second, follow-up project, conducted by UN Women between 2011 and 2013 centered on the implementation and cross-country exchanges of experiences and knowledge about the GRB 
process (UN Women 2015). The third project (2013-2016), which included Moldova, had three objectives - better reflection of gender equality concerns in sectoral programs and budgets at the central and local levels, better oversight of local government programs in pursuit of gender equality commitments, and exchange of knowledge that would facilitate replication of good practices and lessons learned. (UN Women 2017) Similar programs were also implemented in Kosovo and in Serbia by UN Women (former UNIFEM) and other UN agencies but with different foci - in Kosovo, GRB was linked to initiatives related to gender-based violence while in Serbia, GRB activities came under the umbrella of the project on women's economic and social rights. In 2018, IMF organized its first workshop on GRB in the Western Balkans in Vienna, Austria. The topics covered in the three-day workshop included "institutional framework for GRB, budget preparation, and budget execution" while discussions "showed a broad consensus about the key role of fiscal policy in helping achieve better gender outcomes - and also how much has still to be done" (Isakova 2018).

The evaluation of the UNIFEM/UN Women GRB projects, conducted in 2017 (UN Women, 2017), found that progress towards gender equality in the region has been uneven despite repeated affirmed commitments to it by the governments of the project countries. The evaluation explained this lack of progress by "socio-cultural factors" such as "persistent patriarchal attitudes and gender stereotypes about men and women's gender roles, responsibilities, and capabilities which have perpetuated discrimination against women." The evaluation reiterated the tendency of external actors, as astutely noted by Tea Hadžiristić (2016), to explain the continued slide of the Western Balkans countries in gender equity measures by the persistence of "traditional values." In her analysis, Hadžiristić (2016) cited a World Bank (2015) report, which asserted that "post-war laws and institutional measures aimed at gender equality have "not yet been fully successful at creating different attitudes towards women and their traditional role in society."” The report, wrote Hadžiristić, pointed to "patriarchal values and the remnants of the communist order as key obstacles to the development of women's rights and prospects in general." Similarly, a 2017 report commissioned by the UK Department for International Development, suggested that "the biggest challenge for improving gender equality is changing the mentality of both women and men towards traditional gender roles" (Browne 2017). A policy brief by the Civil Society Forum of the Western Balkans (European Fund for the Balkans 2018) also insisted 
that "gender stereotypes are an underlying cause for almost all other forms of discrimination and a reason for the persistently subordinated position of women."

As Daniela Lai demonstrates in her contribution to this special issue, international aid organizations in general and IFIs in particular, have actively neglected socialist legacies and the gendered consequences of war-time violence. Using war as an excuse to treat Western Balkan countries as economies without the past, IFIs have also aimed to re-imagine the gender roles within them, often pushing women back into their stereotypical roles and “women's jobs' such as handicraft and knitting" (Lai, this issue). At the same time, other structural factors - the collapse of healthcare systems, lack of childcare help and facilities, significant out-migration have forced women into household care duties, the informal economy, and subsistence living off family remittances, rendering them "inactive" from a statistical point of view. As a result, women's positions in society - and gender relations overall - have deteriorated to the point of non-recognition in comparison to the roles they played in the former Yugoslavia, where women - on all levels of workplace hierarchies - actively participated in decision-making (Spehar 2012).

In truth, the effectiveness of GRB projects in the countries of the Western Balkans, with their estimated cost of 6-10 million Euros, has not been easy to establish. In the already mentioned evaluation of UNIFEM/UN Women projects, the reviewers attempted to calculate the return on project investment but found the exercise deeply problematic, even if the return was calculated in terms of time, so much so that "the final analysis was removed from the final evaluation evidence" (UN Women 2017). The evaluation nonetheless concluded that "UN Women GRB interventions have contributed substantively to enhancing institutional capacity and practice of gender responsive budget-processes and expenditure planning.” Andrea Spehar's (2018) extensive study of GRB implementation found that in the Western Balkans, it took the "'path of the least resistance," advancing only where GRB measures are not too demanding in terms of cost, time or expertise." Such approach is consistent with the unique challenges of fiscal policy making in post-conflict settings (Van der Boogard et al. 2016) and with the political economy legacies of conflict and transition against which economic policy advice championed by the IFI's is provided. Even the most advanced GRB measures - as in Albania or Macedonia, where budgets have been allegedly aligned with gender equality objectives (Quinn 2016) - may not be able to remedy gendered inequalities embedded in the models of economic growth or tax 
structures promoted by IFIs. The key reason why the projects such as the UNIFEM/UN Women programs in Western Balkans (and the subsequent IMF training) are so limited in their reach is because they remain "focused on budget process and expenditure but exclude macroeconomics and revenue." And as the previous two sections have detailed, even when the combination of consumption-led growth and financialization with an introduction of VAT may have helped increase government revenue, this has been at a tremendous cost to households and, particularly, women.

\section{Conclusion}

In this article, using the example of the IMF's support to post-war reconstruction and transition to open market economy in the Western Balkans, we have examined the gendered impact of the conventional economic policies promoted by the IFIs in the light of recent drives to promote gender equality outcomes through GRB. Our main objective was to expose structural limitations on GRB's effectiveness, directly caused by other - often simultaneous - reforms and policies promoted by IFIs, with a particular emphasis on taxation decisions.

Citing Margaret Mitchell, the author of Gone with the Wind, Christine Lagarde (2017) links women's empowerment and domestic resource mobilization in a bond of inevitability: "Death, taxes, and childbirth. There's never any convenient time for any of them." However, while "all three are central to our lives," it is taxes, believes Lagarde, that "can boost development in incredible ways - from healthcare to education to security." Prioritizing taxation over life-cycle and reproduction, Lagarde thinks, would help build "virtuous cycles" of "improved infrastructure, better compliance, and stronger growth."

Experiences from the Western Balkans tell us otherwise. The combination of consumption-led growth and financialization with VAT as the dominant form of taxation produces a vicious circle of gendered inequalities, even when generating revenue for government coffers. The assumptions of how the transmission chains linking economic growth, women's economic 
empowerment and fiscal policy decisions (both on spending and revenue generation) operate and affect gender equality outcomes have proven shaky in an economic environment of reduced productive capacity. Structural shifts in the economy characterized by pronounced productionconsumption disbalance due to accelerated deindustrialization have undermined job creation, increased employment precariousness, weakened the fiscal base and with it the scope of welfare spending, while financialization has fuelled reliance on consumer debt to make up for the erosion in household budgets.

GRB owes its ascendance to the recognition of the costs to economic output and general wellbeing from neglecting the gender dimension of budgets. Inequities created through growth models based on externally-funded consumer debt and revenue mobilization which place the burden of taxation onto households (and particularly on women within those households), cannot be remedied by gender mainstreaming initiatives such as GRB, which woefully ignore limited economic opportunities available to women in difficult settings of post-war reconstruction and economic and political transition. Nor can they on their own compensate for the disregard of the various ways in which 'growth friendly' fiscal consolidation, and the political decision and incentives driving budget allocations, affect women's role in the economy and their position in the household. Instead, GRB as currently practiced in the Western Balkans and beyond, "reinforces the current status quo and the underlying orthodox paradigm." (Weinhold and Brodtmann 2017).

For all its rhetoric to the contrary, the IMF's practice remains inadequate to address such negative outcomes. Its policy advice rarely comes with any form of distributional or gender analysis (ActionAid 2018). Rather, the prevailing logic seems to be that, one (IFI!) can ignore how revenue is collected and assume it is spent well (Bretton Woods 2019), which as our analysis of IMF policies in the Western Balkans demonstrates is deeply problematic. The most damaging effect from the cumulative effects of economic policies of austerity and revenue raising through VAT in the Western Balkans has been on single women and women-headed households, two of the most vulnerable groups. 
Focusing on gender and revenue mobilization makes it quite obvious how deeply troubling and troubled are today's tax systems, where corporate taxes continue to decline and regressive taxes, such as VAT, proliferate. While most political battles - including those over austerity measures in the post-global financial crisis world - revolve around government spending, structural limitations to GRB's effectiveness in the Western Balkans remind us the way that revenue is raised may be just as if not more important than how it is being distributed.

The evaluators of the GRB projects in the Western Balkans suggest that "framing GRB in terms of economic growth and security concurrently with its current framing within women's human rights" is a way of countering populist and authoritarian tendencies in the region and ensuring future viability of the project (UN Women 2017). But this strategic emphasis on discourses of growth and security for the sake of political feasibility of the GRB projects also betrays the extent to which GRB promoters may be willing to compromise with local and transnational neoliberal economic agendas just to stay in the game. For the civil society advocates and scholars committed to tax and gender equality such activities and such framing cannot be read in any other way but as, in Spehar's terms, “pseudo-activities," pushed forward by international organizations and now IFIs at the risk of instrumentalizing gender that the early advocates of GRB had so warned against.

Word count: 12,108

\footnotetext{
${ }^{1}$ In this article, the Western Balkans includes: Albania, Bosnia and Herzegovina; Croatia, Kosovo, FYR Macedonia, Montenegro and Serbia. In January 2019, FYR Macedonia changed name to the Republic of North Macedonia. 2 There were some notable country variations; for example in Montenegro, credit expansion relied mostly on external sources while a rise in domestic deposits, partly to do its strong remittances was more important in in Albania and Kosovo (Murgasova et al. 2015:71).

${ }^{3}$ According to Matti Kohonen of ActionAid, when IMF staff is asked about how Christine Lagarde's words on gender being macro-critical in tax policy are implemented, "what we hear [...] is push-back on gendered impacts of VAT, that as long as its revenues are spent well, it will be fine for women" (Bretton Woods 2019).

${ }^{4}$ Tax system and tax policy in Kosovo were created by UNMIK. Until the declaration of independence in 2008, the central fiscal authority rested with the UN Special Representative of the Secretary General. Fiscal Economic
} 
Council was partly staffed by Kosovars and had an advisory role. After declaration of independence, fiscal sovereignty moved to local institutions and the Kosovo government immediately took to reforming VAT rates. It increased standard rate (from $16 \%$ to $18 \%$ ), and introduced a reduced rate (8\%) for some categories, alongside $0 \%$ rated goods. At the same time, however, Kosovo has a very low rate of tax compliance, especially in personal income taxes, so VAT represents a disproportionately high percent of tax revenue - almost $80 \%$.

ActionAid (1998). Short-changed: How the IMF's tax policies are failing women. Johannesburg.

Aizenman K., Jinjarak Y., Jungsuk K. and Donghyun, P. (2015). Tax revenue trends in Asia and Latin America: A comparative analysis. NBER Working Paper No. 21755.

ALTAX (2016). Taxation trends in the Western Balkans. Tirana: ALTAX.

Appel, H. (2011). Tax Politics in Eastern Europe: Globalization, Regional Integration and the Democratic Compromise. Ann Arbor: University of Michigan Press

Appel, H., \& Orenstein, M. A. (2013). Ideas versus resources: explaining the flat tax and pension privatization revolutions in Eastern Europe and the former Soviet Union. Comparative Political Studies 46(2), 123-152.

Atoyan, R.V. and Rahman, J. (2017). Western Balkans: Increasing women's role in the economy, WP 17/194. Washington DC: International Monetary Fund.

Bakker, I. (2001). Engendering the economics of globalization. In Stanford, J., Taylor, L., \& Houston, B. (eds.) Power, Employment and Accumulation: Social Structures in Economic Theory and Policy. Armonk, NY: M.E. Sharpe, 219-237 
Barnett, K. and Grown, C. (2004). Gender impacts of government revenue collection: the case of taxation. London: Commonwealth Secretariat.

Bartlett, W. (2009). Economic development in the European super-periphery: Evidence from the Western Balkans. Economic Annals 54(181), 21-45

Bastiaens, I. and Rudra, N. (2018). Democracies in Peril: Taxation and Redistribution in Globalizing Economies. Cambridge: Cambridge University Press.

Bastian, J. (2010). External anchors to the rescue: Reaching out in a time of economic and financial sector crisis in South Eastern Europe. Occasional Paper no. 10.10. Oxford: St Anthony's College.

Bastian, J (2008). Cry wolf no more: External anchors and internal dynamics in the Western Balkans. Journal of Southeast European and Black Sea Studies 8(4), 324-44.

Becker, T., Daianu, D., Darvas, Z., Gligorov, V., Landesmann, M., Petrovic, P., ... Weder de Mauro, B. (2010). Whither growth in Central and Eastern Europe? Policy lessons for an integrated Europe. Bruegel Blueprint Series No. 11, November 2010. Accessed at http://aei.pitt.edu, 25/ November/2017.

Birchall, J. and Fontana, M. (2015). The gender dimensions of expenditure and revenue policy and systems. London: UK Aid-IDS.

Braütigam, D.A., Fjeldstad, O. and Moore, M. (eds.) (2008) Taxation and State-Building in Developing Countries: Capacity and Consent. Cambridge: Cambridge University Press.

Bretton Woods Project (2019). Taxes, taxes, taxes: Shifting the IFIs narrative to progressive gender-just taxation. Accessed at https://www.brettonwoodsproject.org/2019/04/taxes-taxestaxes-shifting-the-ifi- narrative- to-progressive-gender-just-taxation/ 10/August/2019. 
Browne, E. (2017). Gender norms in the Western Balkans. K4D Helpdesk Report commissioned by the UK Department of International Development. Accessed at https://assets.publishing.service.gov.uk/media/597860fced915d312c000007/058-Gender-in-theBalkans.pdf 7/December/2018.

Budlender, D. and Hewitt, G. (2002). Gender budgets make more cents: Country studies and good practice. London: Commonwealth Secretariat.

Budlender, D. et al. (2002). Gender budgets make cents: understanding gender responsive budgets. London: Commonwealth Secretariat.

Buenaventura, M. and Miranda, C. (2017). The IMF and Gender Equality: VAT. London: Bretton Woods Project.

Casale, D. M. (2012). Indirect taxation and gender equity: Evidence from South Africa. Feminist Economics, 18(3), 25-54.

Civil Society Forum of the Western Balkans (2018). Gender Issues in the Western Balkans. CSF Policy Brief 04, April. Accessed at http://wb-csf.eu/docs/Gender_Issues.pdf.pdf 7/December/2018 10/May/2019.

Crnogorac, M. and Santiago Lago- Peñas, S. (2018). Tax evasion in former Yugoslavian countries. Vigo: Universidada Vigo. Governance and Economics Research Network. Working Paper 1811.

Dabla-Norris, E. and Kochhar, K. (2019). Closing the Gender Gap. Finance and Development 56 (1) Accessed at https://www.imf.org/external/pubs/ft/fandd/2019/03/closing-the-gender-gapdabla.htm 16/August/2019. 
Damiani, M. and Uvalić, M. (2018). Structural change in the European Union and its periphery: Current challenges for the Western Balkans. Southeastern Europe 42(2), 145-76.

Di John, J. (2006). The political economy of taxation and tax reform in developing countries. United Nations University-World Institute for Development Economics Research. Research Paper No. 2006/74.

EBRD (2009). Transition Report. London: European Bank for Reconstruction and Development.

Edwards, S. (2017) Economically empowering women is 'macrocritical' - IMF chief Christine Lagarde. DEVEX. March 8. Accessed at https://www.devex.com/news/economicallyempowering-women-is-macrocritical-imf-chief-christine-lagarde-89786 16/August/2019

Elson, D (2001). Gender Responsive Budget Initiatives: Key Dimensions and Practical Examples. In Judd, K. (ed) Gender Budget Initiatives: Strategies, Concepts and Experiences; Papers from a High Level International Conference 'Strengthening Economic and Financial Governance Through Gender Responsive Budgeting. Brussels, 16-18 October. New York: The United Nations Development Fund for Women.

Elson, D. (2010). Gender and the global economic crisis in developing countries: A framework for analysis. Gender and Development 18(2), 201-12.

Elson, D. (2002). Integrating gender into government budgets within a context of economic reform. In Budlender et al. (eds) Gender budgets make cents: Understanding gender responsive budgets, 23-47. London: Commonwealth Secretariat.

Elson, D. \& Cagatay, N. (1999). Engendering macroeconomic policy and budgets for sustainable development. Documento presentado en el Primer Foro Global de Desarrollo Humano PNUD, Nueva 
York, 29. Accessed at

http://www1.aucegypt.edu/src/macroeconomics/PDFS/Elson\%20and\%20Cagatay.pdf and 17/August/2019.

Enriquez, C. and Elson, D. (2012). Taxing for gender economic justice. Development 55(3), 299-304.

Estrin, S. and Uvalić, M. (2016). Foreign direct investment in the Western Balkans: What role has it played during transition?. Comparative Economic Studies 58(3), 455-83.

European Fund for the Balkans and European Policy Centre - CEP. (2018) Gender Issues in the Western Balkans. Civil Society Forum of the Western Balkan Summit Series. CSF Policy Brief No. 04. Accessed at https://wb-csf.eu/docs/Gender_Issues.pdf.pdf 17/August/2019

Farnsweden, U., Qosaj-Mustafa, A. and Farnsworth, N. (2014). Country gender profile: An analysis of gender differences at all levels in Kosovo. Stockholm: ORGUT Consulting AB.

Frunza, M. (2017). Assessment of EU's VAT gap due to shadow economy. Accessed at https://ssrn.com/abstract=3077321 10/June/2019.

Ganev, V. (2011). The annulled tax state: Schumpeterian prolegomena to the study of postcommunist fiscal sociology. Communist and Post-Communist Studies 44(4), 245-255.

Genschel, P., \& Seelkopf, L. (2016). Did they learn to tax? Taxation trends outside the OECD. Review of International Political Economy 23(2), 316-344.

Grown,C. and Valodia,I. (Eds) (2010). Taxation and gender equity: A comparative analysis of indirect taxes in developing and developed countries. London: Routledge. 
Hadžiristić, T. (2016). Is Bosnia the worst place in Europe to be a woman?. Open Democracy, December 5. Accessed at https://www.opendemocracy.net/can-europe-make-it/tea-hadziristic/women-in-bosnia 7/December/2018.

International Monetary Fund (2014). Boosting jobs growth in the Western Balkans, Working Paper No 14/16, Washington DC; International Monetary Fund.

International Monetary Fund (2015). Bosnia and Herzegovina selected issues, Country report No 15/299, Washington DC: International Monetary Fund.

International Monetary Fund (2016). Albania selected issues, Country report No 16/143, Washington DC: International Monetary Fund.

International Monetary Fund (2017). Regional economic outlook: Europe hitting its stride, Washington DC: International Monetary Fund.

International Monetary Fund (2018). How to Operationalize Gender in Country Work? Accessed at https://www.imf.org/en/Publications/Policy-Papers/Issues/2018/06/13/pp060118howto-note-on-gender 16/August/2019.

Isakova, A. (2018). IMF Workshop on Gender Budgeting in South-Eastern Europe. Joint Vienna Institute website. Accessed at https://www.jvi.org/news/detail/article/imf-workshop-on-gender-budgeting-insouth-eastern-europe.html 16/August/2019

James, K. (2015). The rise of the value added tax. Cambridge: Cambridge University Press. 
Keen, M., \& Lockwood, B. (2010). The causes and consequences of the VAT revolution: An empirical investigation. Journal of Development Economics 92, 138-151.

Kentikelenis, A.E., Stubbs, A.E. and King, L.P. (2016). IMF conditionality and development policy space, 1985-2014. Review of International Political Economy 23(4), 543-82.

Kosczan, Z. (2015). Fiscal deficit and public debt in the Western Balkans: 15 years of transition. Washington DC: IMF WP 15/72

Lagarde, C. (2016). Revenue Mobilization and International Taxation: Key Ingredients of 21stCentury Economies by IMF Managing Director Christine Lagarde. International Monetary Fund. Accessed at https://www.imf.org/en/News/Articles/2015/09/28/04/53/sp022216 16/August/2019

Lagarde, C. (2017). Building a virtuous cycle: The IMF's commitment to capacity development and domestic resource mobilization. Accessed at https://www.imf.org/en/News/Articles/2017/06/07/sp060717-building-a-virtuous-cycle 10/June/2019.

Lagarde, C. and Ostry, J.D. (2018) "Economic Gains from Gender Inclusion: Even Greater than you Thought.” November 28. International Monetary Fund Blog. Accessed at https://blogs.imf.org/2018/11/28/economic-gains-from-gender-inclusion-even-greater-than-youthought/ 16/August/2019.

Makrevska- Disoska (2017). Integration in the European Union as a double- edged sword for the Western Balkans. Journal of Liberty and International Affairs 3(1), 26-36.

Mommani B. and Hibben, M.R. (2018). What's wrong with the IMF and how to fix it. Cambridge: Polity Press. 
Murgasova, Z., Ilahi, N., Miniane, J., Scott, A., Vladkova-Hollar, I. and an IMF Staff Team (2015). The Western Balkans 15 years of economic transition. Washington DC: International Monetary Fund.

OECD (1998). Value- added taxes in Central and Eastern European countries: A comparative survey and evaluation. Paris: Organisation for Economic Cooperation and Development.

OECD (no date) Why care about taxation and gender equality? Accessed at https://www.oecd.org/dac/gender-development/44896295.pdf 16/August/2019

Perrons, D. (2017). Gender and inequality: austerity and alternatives. Intereconomics 52 (1), 28-33.

Prügl, E. (2017). Neoliberalism with a feminist face: Crafting a new hegemony at the World Bank. Feminist Economics 23(1), 30-53.

Rodik, P. (2012). Kreditna zaduženost i pad životnog standarda. Zagreb: Udruga Franak.

Reinsberg, B., Stubbs, T., Kentikelenis, A., \& King, L. (2017). “Do IMF programs help raise tax revenue?” Accessed at https://www.peio.me/wp-content/uploads/2018/01/PEIO11_paper_38.pdf. 16/August/2019.

Quinn, S. (2016). Europe: A survey of gender budgeting efforts. Washington DC: IMF Working paper 16/155. Accessed at https://www.imf.org/external/pubs/ft/wp/2016/wp16155.pdf, 7/June/2018. 
Sanfey, P., Milatović, J. and Kresić, A. (2016). How the Western Balkans can catch up. Working Paper No. 186, London: EBRD.

Sawer, M. (2012). Gender budgeting. Gender Institute. Australian National University. Accessed at http://genderinstitute.anu.edu.au/gender-budgeting 17/August/2019.

Seelkopf, L., Lierse, H., \& Schmitt, C. (2016). Trade liberalization and the global expansion of modern taxes. Review of International Political Economy 23(2), 208-231.

Sharp, R., \& Elson, D. (2008). Improving budgets: A framework for assessing gender responsive budget initiatives. Audit Gender Terhadap Anggaran di Indonesia, 46-56. Accessed at https://www.unisa.edu.au/siteassets/episerver-6-files/documents/eass/hri/gender-budgets/sharp-elsonimproving-budgets.pdf 17/August/2019

Spehar, A. (2012). 'This far but no further? Benefits and limitations of EU gender equality policy making in the Western Balkans. East European Politics and Societies 26(2), 362-379.

Spehar, A. (2018). The pursuit of political will: decision makers' incentives and gender policy implementation in the Western Balkans, International Feminist Journal of Politics 20 (2), 236-250

Stotsky, J. (1996). Gender bias in tax systems. Working Paper (WP/96/99). International Monetary Fund.

Stotsky, J. (1997). How tax systems treat men and women differently. Finance \& Development. March. 30-33. Accessed at https://www.imf.org/external/pubs/ft/fandd/1997/03/pdf/stotsky.pdf 17/August/2019 
Stotsky, J. G. (2016). Gender budgeting; Fiscal context and current outcomes. IMF Working Paper WP/16/149 Accessed at https://www.imf.org/external/pubs/ft/wp/2016/wp16149.pdf 20/July/2018.

Stubbs, P. and Zrinščak, S. (2009). Croatian social policy: The legacies of war, state-building and Europeanisation. Social Policy and Administration 43(2), 121-135.

Swank, D. (2016). The new political economy of taxation in the developing world. Review of International Political Economy 23(2), 185-207.

Swank, D. (2016a). Taxing choices: international competition, domestic institutions and the transformation of corporate tax policy. Journal of European Public Policy 23(4), 571-603.

Swank, D., \& Steinmo, S. (2002). The new political economy of taxation in advanced capitalist democracies. American Journal of Political Science, 46(3), 642-655.

True, J. and Svedberg, B. (2019). WPS and International Financial Institutions in Davis, S.E. and True, J. (eds). The Oxford Handbook of Women, Peace and Security. (Oxford, UK: Oxford University Press.) Accessed at https://www.oxfordhandbooks.com/view/10.1093/oxfordhb/9780190638276.001.0001/oxfordhb9780190638276-e-34 17/August/2019.

Udovički, K. and Knaus, G. (2012). Mass unemployment in the Balkans- a need to act. Brussels.

UNIFEM (2010). Gender-responsive budgeting in South Eastern Europe: UNIFEM Experiences. Accessed at https://www.unwomen.org/-

/media/headquarters/media/publications/unifem/grb\%20kp\%20final\%20web.pdf?la=en\&vs=101 2 17/August/2019. 
UN Women (2015) Promoting gender-responsive policies and budgets:

Lessons from South East Europe experiences in the period 2011-2013. Accessed at

https://www2.unwomen.org/-

/media/field\%20office\%20eca/attachments/publications/2016/promoting\%20gender\%20responsive\%20p

olicies\%20and\%20budgets-south\%20east\%20europe-\%202011-2013.pdf?la=en\&vs=5132

17/August/2019.

UN Women (2017). Evaluation of UN Women's contribution to gender responsive budgeting in the Europe and Central Asia Region.

Van den Boogard, V, Prichard, W., Miličić,N. and Benson, M. (2016). Tax revenue mobilization in conflict-affected countries. Helsinki: WIDER. Working Paper 2016/155.

Weinhold, L. and Brodtmann, C. (2017). 'The Gender strategy of the IMF: The way to go towards gender equality or a mere instrumentalisation of feminism?' Exploring Economics. Accessed at https://www.exploring-economics.org/en/discover/gender-strategy-imf/ 20/July/ 2018.

WIIW (2017). Western Balkans labor market trends 2017. Vienna: Vienna Institute for International Comparative Economics. Report No 11.

Women's Budget Group (2017). What is gender budgeting? Accessed at https://wbg.org.uk/resources/what-is-gender-budgeting/ 17/August 17/2019. 
World Bank (2017a). The Western Balkans: Revving up the engines of growth and prosperity. Washington DC: World Bank.

World Bank (2017b). The Western Balkans regular economic report: Faster growth, more jobs. Washington DC: World Bank.

World Bank (2015). Gender disparities in endowments, Access to economic opportunities and agency. Sarajevo, Bosnia and Herzegovina: World Bank, Agency for Statistics of Bosnia and Herzegovina, FBiH Institute for Statistics and RS Institute for Statistics.

World Bank (2008). Public expenditure polices in Southeast Europe. Washington DC. Retrieved from

https://openknowledge.worldbank.org/bitstream/handle/10986/6370/427760PUB0ECA0101OFFIC IAL0USE0ONLY1.pdf; sequence=1 10/May/2018.

World Bank Group (2015). World Bank Group Gender Strategy (FY16-23): Gender equality, poverty reduction and inclusive growth. World Bank, Washington D.C. Accessed at https://openknowledge.worldbank.org/handle/10986/23425 16/August/2019.

Acknowledgment

We are grateful to Janet Stotsky, Jacqui True, our anonymous reviewers, and RIPE editors on their substantive and editorial comments on several drafts of this article. The ultimate responsibility for its content rests, of course, with the authors. 
Table 1 IMF lending arrangements in the Western Balkans

\begin{tabular}{|c|c|c|c|c|c|c|c|}
\hline & Albania & $\mathrm{BH}$ & Croatia & Kosovo & FYRM & Montenegro & Serbia \\
\hline $\begin{array}{l}\text { Systemic } \\
\text { Transformation } \\
\text { Facility }\end{array}$ & 1997 & & 1994 & & & & \\
\hline $\begin{array}{l}\text { Emergency } \\
\text { post-conflict } \\
\text { assistance }\end{array}$ & & 1995 & & & & 2000 & 2000 \\
\hline $\begin{array}{l}\text { Stand-by } \\
\text { Agreement } \\
(\text { SBA) }\end{array}$ & 1992 & $\begin{array}{l}1998 ; 2002 \\
2009 ; 2012\end{array}$ & $\begin{array}{l}1994 ; 2000 \\
2003^{\circ} ; 2004^{\circ}\end{array}$ & $\begin{array}{l}2010 ; \\
2012 ; \\
2015\end{array}$ & $\begin{array}{l}1995 ; \\
2003\end{array}$ & 2011 & $\begin{array}{l}2001 ; \\
2009 ; \\
2011 ; \\
2005\end{array}$ \\
\hline $\begin{array}{l}\text { Extended Fund } \\
\text { Facility }\end{array}$ & 2014 & 2016 & 1997 & & $\begin{array}{l}2000 ; \\
2005\end{array}$ & & \\
\hline $\begin{array}{l}\text { Precautionary } \\
\text { Liquidity line }\end{array}$ & & & & & 2011 & & 2011 \\
\hline $\begin{array}{l}\text { Enhanced } \\
\text { Structural } \\
\text { Adjustment/ } \\
\text { PRG }\end{array}$ & 1997 & & & & & & \\
\hline $\begin{array}{l}\text { Compensatory } \\
\text { Contingency } \\
\text { financing }\end{array}$ & & & & & $\begin{array}{l}\text { 1997; } \\
2000\end{array}$ & & \\
\hline Extended CF & $\begin{array}{l}1993 ; 1 \\
998 \\
2002 ; 2 \\
006\end{array}$ & & & & $\begin{array}{l}1997 ; \\
2000\end{array}$ & & \\
\hline
\end{tabular}

Source: IMF Accessed at: https://www.imf.org/en/Countries (various years); ${ }^{\circ}$ precautionary 
Table 2. Western Balkans VAT rates

\begin{tabular}{|c|c|c|c|}
\hline & $\begin{array}{l}\text { Date VAT } \\
\text { introduced }\end{array}$ & $\begin{array}{l}\text { Original VAT } \\
\text { rate }\end{array}$ & Current VAT rate \\
\hline Albania & 1996 & $20 \%$ & $20 \%$; reduced \% \\
\hline $\begin{array}{l}\text { Bosnia and } \\
\text { Herzegovina }\end{array}$ & 2006 & $17 \%$ & $17 \%$ \\
\hline Croatia & 1998 & $\begin{array}{l}22 \%, 0 \% \text { some } \\
\text { financial services }\end{array}$ & $\begin{array}{l}25 \% ; \text { reduced } \\
13 \% ; 0 \%\end{array}$ \\
\hline Kosovo & 2001 & $15 \% ; 0 \%$ & $18 \%$; reduced $8 \%$ \\
\hline FYR Macedonia & 2000 & $18 \%$ & $18 \%$; reduced $5 \%$ \\
\hline Montenegro & 2003 & $\begin{array}{l}17 \% ; \text { reduced } \\
7 \% ; 0 \%\end{array}$ & $\begin{array}{l}19 \% ; \text { reduced } \\
7 \% ; 0 \%\end{array}$ \\
\hline Serbia & 2005 & $18 \%$ & $\begin{array}{l}20 \% \text {; reduced } \\
10 \%\end{array}$ \\
\hline
\end{tabular}

Source: ALTAX (2016).Taxation trends in the Western Balkans 2016. Tirana: Altax. 